\title{
How leverage can improve performance
}

\author{
Miroslav $\mathrm{Kmet}^{\prime} \mathrm{ko}^{1 *}$, and Eduard Hyránek ${ }^{2}$ \\ ${ }^{1}$ University of Economics in Bratislava, Faculty of Business Management, Department of Business \\ Finance, Dolnozemská cesta 1, 85235 Bratislava, Slovakia \\ ${ }^{2}$ University of Economics in Bratislava, Faculty of Business Management, Department of Business \\ Finance, Dolnozemská cesta 1, 85235 Bratislava, Slovakia
}

\begin{abstract}
One of the best-known Capital Asset Pricing Model (CAP/M) provides us with a methodology for measuring the relationship between the risk premium and the impact of leverage on expected returns. However, this model is not used only to value the cost of capital but also to evaluate the performance of managed portfolios. We will test how the expected return changes in percent by changing the debt-equity ratio and the tax rate based on following assumptions: market return $7 \%$, risk-free rate of return $1 \%$ and beta 1.2 . These assumptions will be constant and we will change the debt-equity ratio and tax rate. Based on these results, it is clear that the change in profitability varies, in relation to the change of the $\mathrm{DE}$ ratio by one tenth. As for changes I $\mathrm{n}$ tax rates, changes in expected profitability are not entirely in direct proportion to these changes.
\end{abstract}

\section{Introduction}

Leverage causes two problems: it increases the company's risk to shareholders and can also cause the company to go bankrupt in bad times. The total risk of the company can thus be divided into business risk (without debt) and financial risk (with debt).

\section{Methods}

We started with characteristics of the model. Subsequently, we used this model with variants by changing variables. These solutions are presented in tabular form. As companies in real life respond to the change in interest rates, we observed the four largest companies in the United States by market capitalization. We also compared the DE ratio with the ROE ratio to prove whether the theory holds.

\footnotetext{
*Corresponding author: miroslav.kmetko@euba.sk
} 


\section{Beta and leverage}

One of the best-known model Capital Asset Pricing Model (CAPM) provide us with a methodology for measuring the relationship between the risk premium and the impact of leverage on expected returns. The model was created by Sharpe [1] and Lintner [2] to estimate the cost of capital for project selection.

A survey by Graham and Harvey [3] that up to $73.5 \%$ of CFOs use this model in decision making. However, this model is not used only to value the cost of capital but also to evaluate the performance of managed portfolios. In the literature we can find many studies that point to different returns using different strategies $[4,5,6]$ and results for equally and value-weighted portfolios $[7,8,9]$. Other studies have shown $[10,11,12]$ that the CAPM applies in January, a month when inflation is usually low, important macroeconomic indicators are announced, and also in months when investors can borrow cheaply. This model is presented as one of the most important model in the financial economy [4,5]. Even Berk and van Binbergen [13] found in their work that this model is closest to the models used by the investor in capital allocation decisions.

Some authors also included macroeconomic factors [14], or human capital [15], or growth in consumption [8].This model has the following basic formula:

$$
R_{s}=R_{f}+\text { Risk premium }
$$

The risk premium is calculated:

$$
R_{s}=R_{f}+\beta\left(R_{m}-R_{f}\right)
$$

If the company has no debt, then in this case the has unlevered beta $\beta^{\mathrm{U}}$, so the company has only business risk, By adding debt to the balance sheet, the company has also financial risk and the beta is called levered beta $\beta^{\mathrm{L}}$.

Then the relationship between the unlevered and levered beta is as follows:

$$
\beta^{L}=\beta^{U}[1+(1-t) D / E]
$$

Or:

$$
\beta^{U}=\frac{\beta^{L}}{[1+(1-t) D / E]}
$$

By modifying the original formula by unlevered and levered be, then we get the equation:

$$
R_{s}=R_{f}+\beta^{U}\left(R_{m}-R_{f}\right)+\beta^{U}[(1-t) D / E]\left(R_{m}-R_{f}\right)
$$




\section{Results}

We will test how the expected return changes in percentage by changing the debt-equity ratio and the tax rate based on the following assumptions: market return $7 \%$, risk-free rate of return $1 \%$, beta 1.2 . These assumptions will be constant and we will change the debt-equity ratio and tax rate.

Table 1. Changes in debt-equity ratio

\begin{tabular}{|c|c|c|c|}
\hline & DE ratio 0,3 & DE ratio 0,33 & DE ratio 0,6 \\
\hline Change in DE & 0 & $10 \%$ & $100 \%$ \\
\hline Beta & 1,2 & 1,22 & 1,36 \\
\hline Return in \% & 8,2 & 8,29 & 9,14 \\
\hline Change in return in \% & 0 & $1 \%$ & $11 \%$ \\
\hline
\end{tabular}

Based on these results, it is clear that the change in profitability varies, in relation to the change of DE ration by one tenth.

Table 2. Changes in tax

\begin{tabular}{|c|c|c|c|}
\hline & Tax rate 25 \% & Tax rate 30 \% & Tax rate 50 \% \\
\hline Change in tax & 0 & $20 \%$ & $100 \%$ \\
\hline DE ratio & 0,3 & 0,3 & 0,3 \\
\hline Beta & 1,2 & 1,2 & 1,2 \\
\hline Return in \% & 8,70 & 8,59 & 8,2 \\
\hline Change in return in \% & 0 & $-1,26 \%$ & $-5,74 \%$ \\
\hline
\end{tabular}

As for the changes in tax rates, the changes in expected profitability are not entirely in direct proportions to these changes, as it was the case in the previous case.

\section{Discussions}

The largest company is characterized as a publicly traded company with the largest market capitalization. Data are as of 31.3.2020. To this date was Microsoft largest company (MSFT) with a market capitalization of 1.2 billion of US dollars. Its historical development of DE ratio for the previous 5 years was: 
Table 3. Historical development of DE ratio of MSFT

\begin{tabular}{|c|c|c|c|c|c|}
\hline & 2015 & 2016 & 2017 & 2018 & 2019 \\
\hline DE ratio & 0.44 & 0.74 & 1.04 & 0.99 & 0.77 \\
\hline
\end{tabular}

If we compare these values with basic interest rate of the US Federal Reserve, we would conclude that the value of the DE ratio of the company changed significantly with the conditions on the credit market.

In 2018, the Fed's key interest rate reached its maximum (within the period under review). If we monitor the interdependence of the DE ratio and ROE, then in 2017 was the value of the ROE indicator the second highest (after 2019).

The second most valuable company is Apple (AAPL) with a market capitalization of 1.11 billion US dollars. Compared to MSFT, the ratio is still increasing.

Table 4. Historical development of DE ratio of AAPL

\begin{tabular}{|c|c|c|c|c|c|}
\hline & 2015 & 2016 & 2017 & 2018 & 2019 \\
\hline DE ratio & 0.54 & 0.68 & 0.86 & 1.07 & 1.19 \\
\hline
\end{tabular}

This company thus not relate to changes in interest rates. On other hand, the increase in debt also leads to an increase in the ROE ratio, which was the highest in the last year.

The third largest company is Amazon (AMZN) with a market capitalization 0,97 billion US dollars. The development of the DE ratio is very similar to MSFT.

The development of the ratio is in the following table.

Table 5. Historical development of DE ratio of AMZN

\begin{tabular}{|c|c|c|c|c|c|}
\hline & 2015 & 2016 & 2017 & 2018 & 2019 \\
\hline DE ratio & 1.06 & 0.79 & 1.37 & 0.76 & 1.02 \\
\hline
\end{tabular}

The DE ratio was also the highest in 2017 and also rose in 2019 when the Fed began to reduce interest rates. However, it is in conflict with previous companies because in 2017 was the ROE indicator the second lowest (after 2015). The increase in indebtedness thus did not support the growth of the ROE ratio.

The latest company is Alphabet (GOOG or GOOGL) with a market capitalization of 0.8 Billion US dollars. Compared to the other previously mentioned companies, it has the lowest values of the DE ratio. This indicator has also not changed significantly. 
Table 6. Historical development of DE ratio of GOOG

\begin{tabular}{|c|c|c|c|c|c|}
\hline & 2015 & 2016 & 2017 & 2018 & 2019 \\
\hline DE ratio & 0.04 & 0.03 & 0.03 & 0.02 & 0.08 \\
\hline
\end{tabular}

This company thus not take an advantage of debt financing. This is also confirmed by the ROE values, which are significantly lower than the previously mentioned companies.

\section{Conclusions}

Some companies seek to take advantage of low interest rates to increase shareholder value, other such as AAPL ignore this possibility. Other large companies are adjusting their DE ratio according to the current situation on the credit market. Another exception concerns Amazon, which has kept the DE ratio low for a long time. This was ultimately reflected in the value of the ROE ratio, which was the lowest of all examined companies.

The article is an partial output of research project VEGA MŠ SR No. VEGA 1/0462/19 entitled Implementation of key determinats into performance models as tools of financial decision-making of the company in the current conditions.

\section{References}

1. W. Sharpe, Capital asset prices: a theory of market equilibrium under conditions of risk. Journal of Finance 19, 425-442, (1964)

2. J. Lintner, The valuation of risky assets and the selection of risky investments in stock portfolios and capital budgets. Review of Economics and Statistics 47, 13-37, (1965)

3. J. R. Graham, C. Harvey, The theory and practice of corporate finance: evidence from the field. Journal of Financial Economics 60, 187-243. (2001)

4. A. W. Lo, Adaptive Markets: Financial Evolution at the Speed of Thought. Princeton, NJ: Princeton University Press. (2017)

5. J. Y. Campbell, Financial Decisions and Markets: A Course in Asset Pricing. Princeton, NJ: Princeton University Press, (2018)

6. J. B. Berk, J. H. van Binsbergen, Assessing Asset Pricing Models Using Revealed Preference. Journal of Financial Economics, 119 (1), 1-23, (2016)

7. N. Chen, R. Roll, S. Ross. "Economic Forces and the Stock Market." Journal of Business, 59, 383-403, (1986)

8. R. Jagannathan, Z. Wang. "The Conditional CAPM and the Cross-Section of Expected Returns." Journal of Finance, 51, 3-53. (1996)

9. R. Jagannathan, Y. Wang. "Lazy Investors, Discretionary Consumption, and the CrossSection of Stock Returns.” The Journal of Finance, 62, 1623-1661, (2007)

10. E. F. Fama, K. R. French, Dissecting Anomalies, Journal of Finance, 63, 1653-1678.

11. D. Li, E. X. N. Li, L. Zhang, Costly External Equity: Implications for Asset Pricing Anomalies, NBER Working Paper 14342. 
12. T. G. Bali, N. Cakici, R. F. Whitelaw, Maxing out: Stocks as Lotteries and the CrossSection of Expected Returns, Journal of Financial Economics, 99, 427-446, (2011)

13. J. B. Berk, J. H. van Binsbergen (2016). Assessing asset pricing models using revealed preference. Journal of Financial Economics 119 (1), 1-23, (2016)

14. P. Jylha, Margin requirements and the security market line. The Journal of Finance $\mathbf{7 3}$ (3), 1281-1321, (2018)

15. T. Hendershott, D. Livdan, D. Rosch Asset pricing: A tale of night and day. Working paper, (2018) 